\title{
The External Dimensions of the EU Legislative Initiatives to Combat Environmental Crime
}

\author{
Ricardo PEREIRA*
}

\begin{abstract}
The recognition of the seriousness and transboundary impacts of environmental crime has led to the adoption of specific legislative initiatives to combat environmental crime at both the international and European level. Yet although the EU member states have adopted successfully in 2008 a legal framework for harmonisation of environmental criminal law, the 1998 Council of Europe environmental crime convention has so far not entered into force, even more than fifteen years since its adoption. This paper examines the legal implications in a scenario in which a EU member state becomes bound by both the Council of Europe and the EU environmental crime instruments. In particular, it examines the extent to which the Council of Europe instrument could affect the EU common rules or alter their scope, thus hindering the external powers of the EU member states to ratify and negotiate independently the Council of Europe convention. This paper also discusses the extent to which the legality of the EU environmental crime directive may be effectively challenged in light of multilateral environmental agreements.
\end{abstract}

Keywords: Environmental Criminal Law; EU External Relations; International Environmental Agreements

\section{INTRODUCTION}

This paper aims to examine the external dimensions of EU environmental crime legislation. In particular, it discusses the relationship between the EU directive on environmental criminal law adopted in October $2008^{\text {rand }}$ the 1998 Council of Europe convention on environmental criminal law ${ }^{2}$ from the perspective of the EU external relations; as well as the extent to which the legality of EU environmental crime legislation may be challenged for incompatibility with international environmental agreements. Although both the EU and Council of Europe environmental crime instruments have been the subject of academic analysis and debate in their own right, there has been little academic analysis of the legal relationship between the two instruments, particularly from the perspective of the EU external relations. In this context, the relationship between EU environmental crime legislation and international environmental agreements will also be examined.

This paper will initially assess whether the EU member states remain competent to adopt and negotiate the 1998 Council of Europe environmental crime convention following the adoption of the EU environmental crime directive in October 2008. Secondly, this paper assesses the extent to which specific provisions of the Council of Europe environmental crime convention are compatible with the

* Senior Lecturer in Law, Cardiff University, Law \& Politics School, United Kingdom. Email: PereiraRi@cardiff.ac.uk This paper was presented in the AEPDIRI conference on 'The Extra-territorial Application of EU Law' that took place in Vigo, Spain, in June 2015. I would like to thank Professor Montserrat Abad Castelos and the two anonymous referees for their helpful comments to earlier drafts of this paper. The usual disclaimer applies.

Directive 2008/99/EC of the European Parliament and of the Council of 19 November 2008 on the protection of the environment through criminal law, Official Journal L 328, 6 December 2008, p. 28-37.

Council of Europe Convention on the Protection of the Environment through Criminal Law, ETS no. I72, 4 November 1998 (not yet in force). 
EU environmental crime directive, as this could affect the ability of the EU member states to adopt and negotiate independently the Council of Europe environmental crime convention. The last section of this paper discusses the extent to which the legality of EU environmental crime legislation may be challenged for incompatibility with international environmental agreements.

\section{THE ADOPTION OF THE COUNCIL OF EUROPE ENVIRONMENTAL CRIME CONVENTION AND THE}

\section{EU ENVIRONMENTAL CRIME DIRECTIVE}

In the early 1990 s there were calls for a comprehensive treaty addressing the growing evidence of the costs and risks associated with environmental criminality. In the seventeenth Conference of European Ministers of Justice (Istanbul, 1990) adopted Resolution No. I, leading the Committee of Ministers of the Council of Europe to set In 1991 a new select committee of experts on the protection of the environment through criminal law, leading to the decision by the Committee to draft a binding international Treaty. ${ }^{3}$ The Council of Europe Convention on the Protection of the Environment through Criminal Law was adopted on 4 November 1998 in Strasbourg (hereinafter, 'Council of Europe/CoE environmental crime convention'). ${ }^{4}$ It was the first international treaty to require more broadly the criminalisation of a number of offences causing or likely to cause environmental damage. 5

The Council of Europe environmental crime convention aims at criminalising environmental harm and harmonising environmental criminal offences and administrative infringements and penalties. The Council of Europe's treaty for a harmonised system of environmental criminal law flows from the idea that criminal law is essential in order to strengthen the protection of the environment, whilst also recognising the effectiveness of other penalties, in particular administrative penalties. In this vein, the Convention aims to establish a minimum standard for a common criminal policy on the protection of the environment. At the time of writing, the Council of Europe Convention has not reached the minimum number of ratifications required for it to enter into force. It has only attracted one ratification by Estonia on 26 April 2002 and a total of fourteen signatures. ${ }^{6}$ Since the convention requires three ratifications for it to enter into force, ${ }^{7}$ it remains inoperative.

In the European Union setting, following a major constitutional challenge regarding the legal basis for the EU legislative initiatives to combat environmental crime, ${ }^{8}$ in February 2007 Commission

\footnotetext{
3 The draft Convention and explanatory memorandum were approved by the European Committee on Crime Problems (CDPC) and adopted by the Committee of Ministers on June/September 1996.

4 Council of Europe Convention on the Protection of the Environment through Criminal Law, ETS no. I72, 4 November 1998 (not yet in force).

See also, F. Comte,'Protection of the Environment through Criminal Law: Destiny of the Various European Union's Initiatives' in Odina, Marco (ed.) Europe and the Environment (Europa Law Publishing, Groningen, 2004) at 46.

6 See http://conventions.coe.int/Treaty/Commun/ChercheSig.asp? NT=172\&CM=8\&DF=3/8/2007\&CL=ENG (accessed on Io February 2015). The states that have signed the convention at the time of writing are: Austria, Belgium, Denmark, Estonia, Finland, France, Germany, Greece, Iceland, Italy, Luxembourg, Romania, Sweden and Ukraine.

7 Article I3 (3) states that the Convention shall enter into force following the period of three months after the date on which three States have expressed their consent to be bound by the convention.

8 See Case C-176/03 ('Environmental Crimes') and Case C-440/o5 ('Ship-Source Pollution').
} 
presented a proposal for a Directive on environmental crimes" based on former Article 175 EC (postLisbon, Article 192 TFEU), superseding the original 200 I environmental crime directive proposal. ${ }^{\text {Io }}$ The 2007 Directive proposal on environmental crimes was negotiated by the Council of Ministers ${ }^{\text {II }}$ and European Parliament ${ }^{\mathrm{I2}}$ following the co-decision procedure. ${ }^{\mathrm{I3}}$ Subsequently, the Draft Report of HartmutNassauer ${ }^{14}$ was approved by the members of the European Parliament Legal Affairs Committee in a close vote ${ }^{\mathrm{Is}}$ on 8 April 2008. The Council and the European Parliament (following the first-reading Plenary session) reached an agreement on the final compromise text of the Directive on 2I May $2008^{16}$ and the Directive was finally adopted with minor amendments by the unanimous vote of the member states represented in the Council on 24 October 2008. ${ }^{17}$ The environmental crime directive requires the member states to criminalise serious environmental offences connected to violations of EC/EU environmental law and contain a general requirement that member states must prescribe 'effective, proportionate and dissuasive' criminal penalties. The Commission thereby hoped that harmonisation of environmental criminal law would help improve the implementation deficit of EC environmental legislation and provide a strong deterrent against transboundary environmental crimes within the EU. ${ }^{18}$

Since the EU member states are already bound by the EU environmental crime directive establishing environmental criminal liability standards, an eventual ratification of the convention by those member states arguably would have limited legal or practical significance. Even though the text of the EU environmental crime directive was influenced by the Council of Europe convention, as will be discussed below, there are considerable differences between the two instruments. Yet one of the advantages of a Council of Europe instrument on environmental crimes over a European Union instrument is that the former could potentially bind a larger number of states than a European Union measure. ${ }^{19}$

9 Proposal for a Directive of the European Parliament and of the Council on the Protection of the Environment through Criminal Law, COM (2007) 5r final, 9 February 2007.

Io Formally withdrawn in the Official Journal2008/C 68/02 on I3 March 2008.

II See for example Working Party on Substantive Criminal Law, Proposal for a Directive of the European Parliament and of the Council on the Protection of the Environment through Criminal Law5152/o8 DROIPEN IENV I2 CODEC I7 II January 2008, available at http://register.consilium.eu.int/

${ }_{12}$ Draft Report on the Directive on the Protection of the Environment through Criminal Law. European Parliament, Committee on Legal Affairs, Rapporteur: HartmutNassauer, 26 February 2008.

I3 The co-decision procedure is set out under Article 294 TFEU (former Article 25I EC).

I4 See Report on proposal for a directive of the European Parliament and of the Council on the protection of the environment through criminal law, A6-0154/2008 of 15 April 2008 [COM(2007)0051 - C6-0063/2007 - 2007/0022(COD)] European Parliament, Committee on Legal Affairs, Rapporteur: HartmutNassauer.

Is 15 Committee members voted in favour while II voted against the proposal. There were two abstentions. See http://www.euractiv.com/en/environment/meps-vote-outlaw-green-crimes/article-I7I498 (accessed Io February 2015).

16 See Position of the European Parliament Adopted at First Reading on 21 May 2008 with a View to the Adoption of the Directive 2008/99/EC of the European Parliament and of the Council on the Protection of the Environment through Criminal Law, available at www.europarl.europa.eu (accessed ro February 2015).

17 Directive 2008/99/EC of the European Parliament and of the Council of is November 2008 on the protection of the environment through criminal law, Official Journal L 328, 6 December 2008, p. 28-37.

I8 See forth Recital to the Explanatory Memorandum to the 2007 environmental crime directive proposal.

19 Presently, the Council of Europe has 47 member states, while the EU has, following the two most recent EU enlargements in 2007 and 2013, 28 Member States. However, it is not necessarily true that the CoE convention would ensure 
It is apparent that there will be insufficient political will by the European governments to boost the ratification process of the Council of Europe environmental crime convention. This is particularly so because the EU member states are themselves already bound by the EU standards under the environmental criminal law directive. So unless the political will across Europe increases for adoption of more effective measures to improve interstate cooperation against environmental crime, it is likely that the $\mathrm{CoE}$ environmental crime convention will face a similar fate to the Lugano Convention on civil liability for environmental damage, ${ }^{20}$ which has not at time of writing attracted one single ratification by the Council of Europe member states, even after more than fifteen years since its adoption. $^{2 \mathrm{I}}$

On the other hand, the adoption of a Council of Europe and EU instruments on environmental criminal law could be regarded as complementary. This would appear to be confirmed by the fact that the Council of Europe has adopted other conventions in the area of criminal law and procedure (including, for example, on cybercrime, corruption and human trafficking) which overlap with the content of EU criminal-law cooperation instruments on those same subjects. It is notable that those conventions are widely ratified. Therefore, those Council of Europe conventions could be regarded as complementary to existing EU criminal-law initiatives. ${ }^{22}$

This suggests that the regionalisation of environmental criminal liability standards in Europe may be confined to the EU Member States for some time. ${ }^{23}$ On the other hand, it might be necessary to control and prevent cross-boundary environmental crime affecting the Council of Europe member states, including cross-border environmental damage involving non-EU states. ${ }^{24}$ This includes cooperation with third-country (non-EU) Council of Europe member states (for example Russia, Ukraine or Turkey). Those could have considerable real and potential cross-border environmental impacts in neighbouring EU member states. Importantly, the most serious nuclear power plant accident in Europe to date (Chernobyl in 1986) happened in Ukraine (not a EU member state, but currently a Council of Europe member state). This accident had considerable cross-border health and environmental impacts not only on neighbouring states in the former Soviet Union, but also on

\footnotetext{
a wider participation than the EU environmental crime directive, as the convention only requires three ratifications for it to enter into force.

20 The Council of Europe Convention on Civil Liability for Damage resulting from Activities Dangerous to the Environment CETS No.: 150 ('the Lugano Convention')

${ }_{21}$ A minimum of three ratifications is required for the convention to enter into force. Similarly, in this case the EU member states are already bound by the EU civil liability directive adopted in 2004. See Directive 2004/35 on Environmental Liability with Regard to the Prevention and Remedying of Environmental Damage [2004] OJ L 143/56.

${ }_{22}$ Compare, for example, the Council of Europe Criminal Law Convention on Corruption CETS No.: I73 and the EU Council Framework Decision 2003/568/JHA of 22 July 2003 on Combating Corruption in the Private Sector, OJ L328 (2003), at 54; OJC195/2 (1997); OJ L279/I (1997); OJ L358/2 (1998); the Council of Europe Convention on Cybercrime CETS no. I85 and the EU Council Framework Decision 2005/667/JHA of 24 February 2005 on Attacks Against Information Systems, OJ L69 (2005), at 67; and Council of Europe Convention on Action against Trafficking in Human Beings, Warsaw, 3 May 2005 (CETS No. 197) and Council Framework Decision 2002/629/JHA of 19 July 2002 on Combating Trafficking in Human Beings, OJ L2003 (2002), at 2).

${ }_{23}$ See R. Pereira, Environmental Criminal Liability and Enforcement in European and International Law (Brill, Leiden, 2015)

24 Ibid.
} 
countries in Eastern and Northern Europe. ${ }^{25}$ Other examples of possible transboundary environmental impacts arising from a Council of Europe (non-EU) member state to EU member states include transboundary pollution from oil and gas activities carried out by Russia in the Arctic sea; or a crossboundary gas pipeline running from Russia to Turkey via the Black Sea controlled by Turkey, such as the proposed Turkey Stream project (Turkey is currently a candidate country, but not a EU member state). Other examples of cross-border environmental impacts arise in the context of illegal fishing and wildlife crime. In this vein, the 2000 International Crime Assessment report released by the US government suggested that Russian crime syndicates are believed to earn as much as $\$ 4$ billion annually from the illegal export of some 2 million metric tons of seafood, including to the European market. ${ }^{26}$

Despite these possible environmental impacts of cross-boundary activities between Council of Europe (non-EU) member states and EU member states, it should also be noted that as part of the enlargement process, candidate countries to EU membership - which includes for example Serbia and Turkey - are required to implement the environmental crime directive in order to comply with the EU's acquis communaitaire. ${ }^{27}$ This suggests that the process of enlargement could lead to broader regionalisation of environmental criminal law standards in Europe beyond the EU member states, even if the situation remains that there is lack of political will by the Council of Europe member states to ratify the environmental crime convention. It should also be noted that the Council of Europe convention is also open for accession by "non-member States which have participated in its elaboration ${ }^{28}$ as well as by other third countries provided that a number of procedural requirements are followed. ${ }^{29}$

Obviously the entering into force of the Council of Europe Convention is not dependant on the ratifications of the EU member states, since it could still enter into force with a minimum of three ratifications including non-EU, Council of Europe member states. Yet this scenario would not be without legal implications for the EU as at least one EU member state (ie. Estonia, the only state to have ratified the environmental crime convention so far) would be bound by both the EU and Council of Europe environmental crime instruments.

25 Marc Lallanilla,Chernobyl: Facts About the Nuclear Disaster, September 25, 20I3, http://www.livescience.com/3996Ichernobyl.html (accessed is February 2015).

26 'According to press reports citing Russian law enforcement estimates' Seethe 2000 International Crime Assessment report. Russia ratified the Convention on Trade in Endangered Species (CITES) in 13/or/r992. See generally, Sally Stoecker and Ramziya Shakirova, Environmental crime and corruption in Russia: federal and regional perspectives (Routledge, London, 2014).

${ }_{27}$ European Neighbourbood Policy and Enlargement Negotiations: Conditions for Membership, http://ec.europa.eu/enlargement/policy/conditions-membership/index_en.htm (accessed I5 February 2015).

28 Art. I3 (I) Council of Europe environmental crime convention. This provision only applies to Canada, which has participated in the drafting of the convention. However, at the time of writing Canada has not yet signed or ratified the convention.

29 Art. I4 of the convention states that "[a]fter the entry into force of this Convention, the Committee of Ministers of the Council of Europe, after consulting the Contracting States to the Convention, may invite any State not a member of the Council of Europe to accede to this Convention (...). This article subjects the accession by a non-Council of Europe member state to the condition that there is 'a decision taken by the majority provided for in Article $20 . d$ of the Statute of the Council of Europe and by the unanimous vote of the representatives of the Contracting States entitled to sit on the Committee." 
The next section examines the extent to which the adoption of the environmental crime directive could have implications for the external competence of the EU member states to negotiate and adopt the CoE environmental crime convention. In particular, it discusses the extent to which the adoption of the EU environmental crime directive in 2008 could hinder the ability of the EU member states to ratify independently the Council of Europe environmental crime convention.

\section{THE EU EXTERNAL COMPETENCE TO NEGOTIATE AND ADOPT INTERNATIONAL ENVIRONMENTAL AGREEMENTS}

The adoption of the EU directive on environmental crimes will have important consequences for the member states' external competence to negotiate and eventually ratify the Council of Europe environmental crime convention. This might require the involvement of both the Union and the member states in the negotiations of the Council of Europe environmental crime convention..$^{30}$ However, it should be noted that the EC has not participated in the negotiations of the environmental crime convention, which only foresees the accession by states, but not regional organisations such as the EC/EU. ${ }^{31}$

According to Article 3 (2) TFEU, the Union has exclusive competence for the conclusion of an international agreement 'insofar as its conclusion may affect common rules and their scope.' So in case the EU exercises its internal competence (for example, through the adoption of the environmental crime directive), this could lead to the exclusivity of the EU external competence. This manner of acquiring exclusive external competences was recognized for the first time by the ECJ in the ERTA case $^{32}$ and was further refined, inter alia, in the Open Skies cases. ${ }^{33}$ Yet for the EU competence to be exclusive following the EU legislative action, the conclusion of an international agreement would have to 'affect common rules or alter their scope.' In order to establish that the conclusion of an international agreement affects common rules or alter their scope, the EU institutions might have to 'specify in detail the aspects of Community legislation which could be prejudiced by the agreement.' ${ }^{34}$

The EU exclusive competence would arise in general when the EU internal legislation involves total harmonization of standards. Minimum harmonization measures, such as the EU environmental

30 See House of Lords, European Union Committee, $42^{\text {nd }}$ Report of Session 2005-2006 'The Criminal Law Competence of the European Community. Report with Evidence' 28 July 2006infra at 45: "Another consequence of moving policing and criminal law into the First Pillar is that if the Community were to act internally (for example, by adopting a Directive on a particular subject) then the Member States wouldlose competence, in favour of the Community, to conclude treaties or other agreements with third States on that subject. Even if the Community rules are only a partial harmonisation, Member States' freedom would berestricted. They would share competence with the Community." Consequently, as Professor Peers pointed out, "almost any future negotiations, certainly at a multilateral level within the Council of Europe, for instance, on international criminal treaties, would involve both the Community and the Member States” (Q iIo)' (para. 158).

${ }_{31}$ See Article I3 (I) and Article 14 of the Council of Europe environmental crime convention. See also, Pereira (n 23)

32 Case 22-70, Commission of the European Communities v Council of the European Communities. Judgment of the Court of 3 I March 197 I

33 Open Skyies case (Case C-466-98 Commission v. UK (2002) ECR I-9427. See further, G. de Baere, 'EU External Action', in C. Barnard and S. Peers (eds.) European Union Law (OUP, Oxford, 2014) at 715.

34 Opinion of Advocate General Tizzano in Open Skyies case (Case C-466-98 Commission v. UK (2002) ECR I-9427; See also, e.g. Case C-467/98 Commission v Denmark ECR I-9519) 
crime directive adopted pursuant to Articles 192 and 193 TFEU, would normally give rise to nonexclusive EU competences. ${ }^{35}$ As the ECJ held in Opinion I/03, the fact that both the Union rules and international agreement in question lay down minimum standards: 'may justify the conclusion that the [Union] rules are not affected, even if the [Union] rules and the provisions of the agreement cover the same area. ${ }^{36}$ This suggests that, in principle, the EU member states would then remain free to negotiate and ratify the Council of Europe environmental crime convention. However, it should be noted that the principle of sincere cooperation in Article 4 (3) TEU could still restrict member states' external actions. This would apply even if the member states were to be acting within their own sphere of competence. ${ }^{37}$

Another problem is that the Council of Europe environmental crime convention does not contain a 'disconnection clause' to protect the future status of Community/Union law, which have become common in the Council of Europe Conventions adopted since $1989.3^{38}$ One example is the Council of Europe convention on civil liability for environmental damage, which states that in their mutual relations, Parties which are members of the European Economic Community shall apply Community rules and shall therefore not apply the rules arising from this Convention except in so far as there is no Community rule governing the particular subject concerned. ${ }^{39}$ According to the Explanatory report to that convention, the purpose of this 'disconnection clause' is twofold: ${ }^{\circ}$ firstly, it aims at permitting the EC member states, when a Convention contains subjects for which the Community has exercised its competence, to sign and ratify the Convention together with the Community without the need to make declarations about the division of their competence. The second purpose of the 'disconnection clause' is to ensure that the 'EEC Member States and the Community would not have to abstain from becoming a Party to the Convention in the case of possible minor discrepancies between the provisions of the Convention and Community rules during the period needed to bring these rules in conformity with the provisions of the Convention. ${ }^{4 \mathrm{I}}$ Yet it has been argued that 'a disconnection clause' to protect the status and future development of Community/Union law in the text of the [Council of Europe] Convention is not strictly necessary. This is because "the same legal result can be deduced from the mixed ratification of the Convention and may be confirmed through a declaratory statement to that effect." ${ }^{42}$

The above analysis suggests that the EU member states remain competent to negotiate and ratify the Council of Europe environmental crime convention so long as it does not 'affect common rules or alter their scope.' The next section discusses the similarities and potential incompatibilities between

35 G. de Baere, supra (n 33).

36 Opinion I/o3, Opinion pursuant to Article 300(6) EC ('Competence of the Community to conclude the new Lugano Convention on jurisdiction and the recognition and enforcement of judgments in civil and commercial matters').

37 de Baere, supra n. 33, at 72I-722.

$3^{8}$ F. Hoffmeister, 'The Contribution of EU Practice to International Law' in M. Cremona (ed.), Developments in EU External Relations Law (OUP, Oxford, 2008).

39 The Council of Europe Convention on Civil Liability for Damage resulting from Activities Dangerous to the Environment CETS No.: 150 ('the Lugano Convention'), Article 25.

40 Explanatory report to the Lugano Convention, Article 25, 88.

4I Ibid.

${ }^{42}$ Hoffmeister, supran. 38, at 69. 
the two instruments, which could have the effect of hindering the ability of the EU member states to negotiate and accede independently to the Council of Europe environmental crime convention.

\section{THE COMPATIBILITY OF THE COUNCIL OF EUROPE ENVIRONMENTAL CRIME CONVENTION WITH THE EU ENVIRONMENTAL CRIME DIRECTIVE}

It is not so clear the extent to which the provisions of the Council of Europe environmental crime convention affect the EU common rules or alter their scope, particularly as the EU and Council of Europe instruments only impose minimum standards, allowing state parties to enhance those standards. As will be discussed in this section, there are considerable differences between the Council of Europe environmental crime convention and the EU environmental crime directive. The differences between the two instruments examined in this section relate to the structure and definition of some criminal offences (including inchoate offences); complicity; criminal penalties and corporate criminal liability rules.

\section{(I) General Structure of Criminal offences}

As regards the general structure of the criminal offences, there is only one autonomous offence in the Council of Europe Convention on environmental criminal law. This offence requires state parties to introduce criminal sanctions irrespectively of whether the underlying conduct is illicit ('unlawful') or not within their legal systems. The autonomous offence relates to the intentional discharge, emission or introduction of a quantity of substances or ionising radiation into air, soil or water [which either] causes death or serious injury to any person, or creates a significant risk of causing death or risk of serious injury to any person. ${ }^{33}$ This offence must be criminalised regardless of its unlawfulness under national law, i.e. the infringement of the law, an administrative regulation or a decision taken by a competent authority. ${ }^{44}$ The objective of this provision is not to leave it to the discretion of the national regulatory bodies the prerogative to grant licences which may risk the life or physical health of humans. Unlike the Council of Europe Convention, the EU environmental crime directive does not contain any autonomous offence. Under the directive, the 'unlawfulness' of the activity is a requirement for all offences. ${ }^{45}$ Therefore, a licence granted to an operator may constitute a defence to all criminal offences under the Directive.

Another difference between the two instruments relate to the definition of abstract endangerment offences. Criminal offences are categorised as 'abstract endangerment' if they do not require a specific result, for example, harm to the environment or human health. The Council of Europe Convention on environmental crime envisages abstract endangerment offences in Article 4, paragraphs a) to e), given that those offences do not require a specific result or environmental damage. This includes the 'unlawful operation of a plant' and the 'unlawful causing of noise'. Since abstract endangerment

\footnotetext{
43 Article 2 (I) (a) of the Council of Europe Convention on environmental crime.Convention on the Protection of the Environment through Criminal Law, Council of Europe, ETS No. 172.

44 See the definition of 'unlawful' under Article I (a) of the Council of Europe Convention.

45 See Article 3 of the environmental crime directive.
} 
criminal offences are not common to all legal systems, the drafters of the Convention left it to the discretion of the State Parties to establish whether such offences are of a criminal or administrative nature. ${ }^{46}$ In contrast, there are only two abstract endangerment offences in the EU environmental crime directive. The illegal shipment of waste contrary to Regulation (EC) No. I013/2006 on shipments of waste, ${ }^{47}$ which includes the shipment carried out without the notification or consent of the competent authorities; ${ }^{48}$ and the 'production, importation, exportation, placing on market or use of ozone-depleting substances. ${ }^{49}$ All the other offences require at least a concrete endangerment to the environment or human health. ${ }^{50}$

By requiring the criminalisation of an autonomous offence, the Council of Europe environmental crime convention imposes a higher standard than the environmental crime directive. Therefore, if a EU member state were to be bound by both instruments, it would have to implement the highest standard and introduce the autonomous offence defined in the Council of Europe convention. In contrast, the convention and the directive list different types of abstract endangerment offences (the unlawful operation of a plant; illegal waste shipment, etc), which means that a EU member state would have to comply with the harmonisation requirements of both instruments, which hence could be regarded as complementary.

\section{(2) Inchoate Offences and Complicity}

Another area in which the Council of Europe and EU environmental crime instruments differ relate the definition of inchoate offences. The criminalisation of inchoate offences is foreseen in Article 4 of the EU environmental crime directive, which states that 'Member States shall ensure that inciting, aiding and abetting the intentional conduct referred in Article 3 is punishable as a criminal offence.' In contrast, the Council of Europe on environmental criminal law only requires the criminalisation of inchoate offences as regards one of the 'intentional' offences under Article 2 (I) of that convention. ${ }^{51}$

Despite the fact that no specific provision on liability for omissions is present in the Council of Europe environmental crime convention, the Explanatory Memorandum explains that the offences under the convention may be committed by acts or omissions, at least in the context of the

${ }_{46}$ Dandachi S. A., 'Convention sur la Protection de L'Environnement', 2 Revue Juridique de L'Environnement(2003), at 284 .

47 Regulation (EC) No. I0I3/2006, OJ L 190, 12.7.2006.

48 Article 3 (c) of the environmental crime directive refers to Article 2 (35) of the Regulation on shipments of waste. This later provision defines illegal shipment as those shipments carried out under certain circumstances including a) without notification to all competent authorities concerned pursuant to this Regulation; or (b) without the consent of the competent authorities concerned pursuant to this Regulation.

49 Article $3(\mathrm{~h})$ of the environmental crime directive. See also Pereira (n 23)

so The offences in environmental crime directive generally require the prohibited activity "to cause" or "[to be] likely to cause" damage or injury to a person or the environment. See Article 3 (a), (b), (d), (e). The offences against protected specimens $(\mathrm{f}-\mathrm{g})$ and protected habitat $(\mathrm{h})$ also apply a specific damage threshold.

${ }_{51} \quad$ Art. 2 (2) of the Council of Europe convention states that Each Party shall adopt such appropriate measures as may be necessary to establish as criminal offences under its domestic law aiding or abetting the commission of any of the offences established in accordance with paragraph I of this article. 
'intentional offences' falling under Article 2 of the convention. ${ }^{52}$ In contrast, Recital 6 of the environmental crime directive clarifies that the offences under the directive may be committed by omissions, in particular the '[f]ailure to comply with a legal duty to act can have the same effect as active behaviour and should therefore also be subject to corresponding penalties.'

The Council of Europe environmental crime convention contains an obligation for states to criminalise complicity in relation to the intentional offences listed in Article 2 (I) only. ${ }^{53}$ So it is not necessary for state parties to criminalise complicity in the case of the offences listed in Article 4 (which may be of a criminal or administrative nature) nor in relation to the negligent offences under Article 3. Similarly, in the course of the decision-making leading to the adoption the EU environmental crime directive, the European Parliament rejected the original proposal for the criminalisation of complicity in the case of non-intentional offences. ${ }^{54}$ This is in light of the fact that in some Member States non-intentional (secondary) participation in a criminal offence is not punishable.55 Hence Article 4 of the environmental crime directive states that "Member States shall ensure that (...) aiding and abetting the intentional conduct referred to in Article 3 is punishable as a criminal offence" (emphasis added). ${ }^{56}$

In general it could be said that that the environmentalcrime directive adopts higher standards in relation to inchoate offences than the Council of Europe convention. Yet it is notable that the directive and Council of Europe convention adopt similar standards as regards the definition ofcomplicity to commit an environmental offence.

\section{(3) Mens Rea and the Degree of Harm}

Under the Council of Europe environmental crime convention, offences are differentiated on the basis of the mensrearequirement. For example, while 'intentional' unlawful transport and disposal of hazardous waste endangering human and animal life fall under article 2 (I) (c) of the convention - for which signatory parties must introduce criminal sanctions - the "unlawful disposal, treatment, storage, transport, export or import of waste" (so non-hazardous wastes or other wastes that are not likely to endanger human and animal life) fall under Article 4 (c) when committed "intentionally or with negligence." $\$ 7$ This means the convention leaves it to the discretion of national Parliaments the choice

52 Commentary III, Section II, of the explanatory memorandum states that Article 2 covers the most serious environmental offences which, whether by an act or an omission, are committed "intentionally".

53 See Article 2 (2) of the 1998 Convention on the Protection of the Environment through Criminal Law, I72: 'Each Party shall adopt such appropriate measures as may be necessary to establish as criminal offences under its domestic law aiding or abetting the commission of any of the offences established in accordance with paragraph i of this article.'

54 See Report on proposal for a directive of the European Parliament and of the Council on the protection of the environment through criminal law, A6-0154/2008 of 15 April 2008 (COM(2007)0051 - C6-0063/2007 - 2007/0022(COD)) European Parliament, Committee on Legal Affairs, Rapporteur: HartmutNassauer, at 17.

${ }_{55}$ For example in English criminal law the mensrea for secondary participation (aiding, abetting, counselling or procuring) is intention. See A.P. Simester and G.R. Sullivan, Criminal Law: Theory and Doctrine (Hart, Oxford, 2007) at 207.

${ }_{56}$ Pereira, supra (n 23)

57 Ibid. 
to adopt criminal or non-criminal sanctions. So the Contracting States to the convention are obliged, in relation to the "hard core" intentional offences under Articles 2, to classify them as "criminal." 58 Moreover, paragraph (I) of Article 3 extends criminal liability to negligent offences. Yet paragraph 2 of Article 3 allows contracting parties, when ratifying the Convention, to limit liability for Article 2 offences to those committed with 'gross negligence.' 59 Under the EU environmental crime directive, member states are required to criminalise a number of prohibited activities committed intentionally or with 'at least' serious negligence. ${ }^{60}$ However, unlike the Council of Europe convention, the EU directive itself does not establish an aggravated liability depending on whether criminal offences are committed with intention, recklessness or negligence. This means that, to the extent that the Council of Europe convention aggravates the liability (in relation to 'intentional' offences), this would be the highest standard to be adopted by a EU member state bound by both environmental crime instruments. In contrast, the EU directive applies, in general, more stringent requirements in relation to offences committed with recklessness or serious negligence, and thus this would be the standard to be implemented.

Moreover, the approach under the Council of Europe Convention on environmental crime is to establish the need for criminalisation relative to the degree of harm or potential harm. The Contracting States to the convention are required to criminalize the "hard core" intentional offences under Article 2, all of which specify a specific degree of harm such as 'death or serious injury to any person or substantial damage to the quality of air, soil, water, animals or plants.' In a similar vein, most offences in the environmental crime directive require a specific result, i.e. that they cause or are likely to cause harm to persons or the environment (air, soil, water, animals or plants). The EU environmental crime directive also contains vague notions of harm such as 'substantial damage,' 'serious injury,' 'significant deterioration' and 'negligible impact' in its definitions of offences. ${ }^{61}$ Yet as the directive only imposes minimum standards, member states may adopt higher standards and criminalise even less serious activities which do not cause or are likely to cause 'substantial damage,' 'serious injury' or 'significant deterioration. ${ }^{62}$ It is clear that in both the Council of Europe and EU instruments on environmental criminal law, the seriousness of the violation of environmental law is paramount to establish a benchmark for criminalisation. In fact, 'seriousness' is a condition for the establishment of the EU competence to lay down environmental offences. ${ }^{63}$ This is reflected in the final text of the adopted 2008 directive, as all offences under the directive are linked to a threshold of serious harm, either actual or potential. As both the convention and the directive use similar terminology to define the seriousness of harm (e.g. 'serious injury', 'significant deterioration') linked

\footnotetext{
58 Those offences should usually carry at least as an alternative sanction the sanction of imprisonment. See Article 6, 2nd sentence of the convention.

59 The Council of Europe convention refers to 'gross negligence', rather than 'serious negligence' applied in the EU environmental crime instruments.

60 See 'caput' of Article 3 of the environmental crime directive.

${ }_{6}$ See Article 3(a)-(h) of the environmental crime directive.

62 See Pereira, supra $\mathrm{n} 23$.

63 See Environmental Crimes (supra n. 8), paras. 47-48.
} 
to specific offences, there appears to be no conflict between the two instruments as regards the definition of the threshold of harm required for establishing a criminal offence.

\section{(4) The range of criminal offences}

The range of offences in the Council of Europe Convention on environmental crime is more comprehensive than under the environmental crime directive. In particular, the Council of Europe convention protects additional forms of environmental media, such as offering legal protection in relation to the unlawful causing of 'noise, ${ }^{64}$ specific legal protection to 'national parks, national reserve, water conservation or other protected areas,' ${ }^{65}$ as well as to 'protected monuments' and 'other protected objects [and] property. ${ }^{\prime 66}$ Hence, unlike the EU environmental crime directive which aims to protect 'any person' and 'air', 'soil', 'water', 'animals' or 'plants,' ${ }^{67}$ the Council of Europe Convention additionally aims at protecting 'property' and other elements of the 'built environment', thus establishing a higher standard than the EU environmental crime directive.

Another difference relates to the definition of specific criminal offences. For example, the pollutioncontrol offences in the environmental crime directive borrow a number of elements from the pollutioncontrol offences under the Council of Europe convention on environmental crime. However, the Council of Europe convention requires the criminalisation only of concrete endangerment pollution-control offences (i.e. those that cause or are likely to cause damage) when committed intentionally or negligently, ${ }^{68}$ but not generally in relation to abstract endangerment pollution-control offences (such as the 'unlawful operation of a plant'), which hence may be regarded as criminal or administrative offences by state parties. ${ }^{69}$ In another example, the Council of Europe Convention does not address directly the trade in ozone depleting substances, although the offence on illegal trade in chemicals could cover illegal trade in ozone depleting substances..$^{70}$ In contrast, the EU environmental crime directive requires the criminalisation of 'the production, importation, exportation, placing on the market or use' of ozone depleting substances. ${ }^{7 \mathrm{I}}$ Therefore, in so far as the EU environmental crime directive requires the criminalisation of pollution-control (non-intentional) offences, or in relation to illegal trade in ozone depleting substances, it could be said that the directive imposes higher standards than those foreseen in the Council of Europe convention.

Aside from the level of harm (as discussed above), it is not always clear why the Council of Europe environmental crime convention "downgrades" certain offences to Article 4 (in relation to which there is no obligation for contracting States to penalise), particularly in the context of wildlife crime. This is a considerable weakness of the Convention, as some potentially very serious environmental offences with transboundary impacts, in particular the "unlawful trade, possession, damaging (...) of protected

${ }_{64}$ Article 4 (b) of the CoE environmental crime convention.

${ }_{65}$ Article 4 (f), ibid.

${ }_{66}$ Article 2 (I) (b), ibid.

${ }_{67}$ See Article 3 of the environmental crime directive.

68 See Articles 2 and 3 of the CoE environmental crime convention.

69 Article 4, d) ibid.

70 See Article 4, e) ibid.

${ }_{71}$ Article $3(\mathrm{i})$ of the environmental crime directive. 
wild flora and fauna species," ${ }^{72}$ only fall under Article 4 and thus there is no obligation on state parties to criminalise such offences. In this regard, it appears that the convention incorporates an 'anthropocentric' approach to environmental protection. Indeed, under the convention 'wildlife' and 'natural habitat protection' crimes (ie "possession (...) or trading of or in protected (...) species" or "changes detrimental to natural components of a national park, natural reserve (...) and other protected areas"), even when committed intentionally, would not necessarily entail criminal sanctions. ${ }^{73}$ In contrast, the environmental crime directive requires the criminalisation of both the illegal trade in endangered species and destruction of natural habitats, and thus adopts a higher standard of environmental protection in the context of wildlife crime. ${ }^{74}$

(5) Criminal liability of corporate entities

A cautious approach to the application of criminal penalties to corporate entities is found in the Council of Europe environmental crime convention. Article 9 (3) of the convention allows any state upon ratification to declare that it reserves the right not to apply the provision under the convention [i.e. Article 9] which establishes the liability of legal persons. ${ }^{75}$ This provision allows signatory parties to enter a reservation in case they do not wish to introduce criminal sanctions to corporations. At the time of writing, Italy is the only signatory state to have entered a reservation under that Article 9 (3) of the convention. Similarly, the environmental crime directive does not require member states to impose criminal sanctions on corporations, thus member states may introduce sanctions of a noncriminal nature to corporate entities. However, the directive goes further to require member states to ensure that the liability of the corporation (which may be of a criminal or civil nature) is linked to the acts of individuals with either: a) the power of representation of the legal person; b) an authority to take decisions on behalf of the legal person; c) or an authority to exercise control. ${ }^{6}$ Although neither the directive nor the Council of Europe instrument require member states to necessarily introduce penalties of a criminal nature to corporations, the EU directive contains more detailed rules establishing the conditions for the liability of corporate entities, and thus adopts a higher standard as regards corporate liability than the Council of Europe convention.

(6) Criminal penalties

As regards the application of criminal penalties, there are important differences between the Council of Europe convention and the EU environmental crime directive. The Council of Europe environmental crime convention does not require Contracting Parties to harmonise the types and levels of criminal penalties (e.g. imprisonment, fines, restoration of the environment) for particular

72 Article 4 (g) of the Council of Europe environmental crime convention.

73 The 'anthropocentric' approach of the convention is further evidenced if one comparesthewidldife offences under Article $4(\mathrm{f})$ and $(\mathrm{g})$ with the 'intentional' offences under Article 2 of the convention, all of which recognise the protection of 'any person' in addition to the protection of elements of the natural environment and/or property. See also, Pereira (n 29)

74 See Article 3 ( $\mathrm{f}$ ) and (g) of the environmental crime directive.

75 Article 9 (3) of the Environmental crime convention.

${ }^{76}$ Article 6 of the environmental crime directive. 
crimes, only containing a general provisions on sanctions. In particular, Article 6 of the convention states that 'the sanctions available shall include imprisonment and pecuniary sanctions and may include reinstatement of the environment' (emphasis added). Moreover, Article 7 of the convention addresses the confiscation of instrumentalities and proceeds of the environmental crime. In contrast, the 2008 environmental crime directive does not prescribe specific types and levels of criminal penalties. ${ }^{77}$ The directive only contains a general requirement that Member States introduce 'effective, proportionate and dissuasive' criminal penalties. Although the provisions on criminal penalties are deficient in both the environmental crime directive and Council of Europe convention, the latter adopts a higher standard by requiring the introduction of specific types of criminal penalties.

\section{THE COMPATIBILITY OF THE EU ENVIRONMENTAL CRIME LEGISLATIVE INITIATIVES WITH MULTILATERAL ENVIRONMENTAL AGREEMENTS}

Aside from the compatibility of the EU and Council of Europe environmental crime instruments, the compatibility of the EU environmental crime directive(s) with international environmental agreements in general is a crucial one to consider. Stephen C. McCaffrey ${ }^{78}$ identified 'penal provisions' in some fifteen multilateral agreements relating to the environment, ${ }^{79}$ as well as several bilateral agreements between states ${ }^{8}{ }^{\circ}$ Most commonly, these instruments require the contracting parties to take 'appropriate measures to ensure the application of the provisions of the agreement [in question] and the punishment of infractions against [those] provisions. ${ }^{81}$ Other approaches include requiring state parties to 'enact and enforce such legislation as may be necessary to make effective the (...) provisions (of the agreement) with appropriate penalties for violations thereof. ${ }^{8_{2}}$ For example, in the context of the transboundary movement of hazardous waste, both the Basel ${ }^{8_{3}}$ and Bamako ${ }^{8_{4}}$

77 This limitation is in light of the Ship-Source Pollution ruling (Case 440/05) in which the ECJ held that the Community did not have the power to define specific types and levels of criminal penalties. However, it is possible that the EU environmental crime directive will be amended inter alia to require that member states adopt specific types and levels of criminal penalties based on the post-Lisbon legal basis established in Article 83 (2) TFEU. See further, Pereira, supra (n23).

$7^{8}$ S. McCaffrey, 'Crimes Against the Environment' in C. Bassiouni (ed), International Criminal Law (Brill, Leiden, 2008), at 989 .

79 See the references to some of these agreements below, including the Convention for the Prevention of Marine Pollution by Dumping of Wastes and Other Matter, 197I, arts. 4 and 7, and CITES (Convention on the International Trade of Endangered Species), art. 8, par. I and the Convention for Prevention of Marine Pollution from Land-Based Sources, I974, art. I2.

8o For example, 'Agreement between Chile, Ecuador and Peru on Regulations Governing Whaling in the Waters of the South Pacific.' (1954) See McCaffrey, supra n. 76, at 990.

${ }_{8}$ See e.g. International Convention for Regulation of Whaling (1946) art. 9; The Convention for Prevention of Marine Pollution by Dumping from Ships and Aircraft (1972) art.I5 (3); Convention on Prevention of Marine Pollution by Dumping of Wastes and Other Matter (1972) arts.4 and 7; The Convention for the Prevention of Marine Pollution from Land-Based Sources (1978) (replaced by the OSPAR Convention) art.I2; Convention on the International Trade of Endangered Species, art 8, par. I.See also, McCaffrey, supra n. 76, at Ior9.

82 Ibid.

83 See Basel Convention on the Transboundary Movement of Hazardous Waste, 1673 UNTS I26 (adopted 22 March 1989, in force 5 May 1992). Article 9, par. 5, reads: "Each Party shall introduce appropriate national/domestic legislation to prevent and punish illegal traffic. The Parties shall co-operate with a view to achieving the objects of this Article" (emphasis added) 
Conventions on the transboundary movement of hazardous wastes contain provisions requiring the use of penal measures, that is, a requirement that states take 'appropriate measures' to ensure the application of the agreement and punishment of violators thereof. ${ }^{85}$ Other examples of international environmental treaties which contain an obligation on States to implement penal measures include the Washington Convention on Illegal Trade in Endangered Species ('CITES') which requires parties to 'penalise trade in, or possession of, such specimens, or both. ${ }^{86}$ Under the convention on the prevention of marine pollution from ships ('MARPOL'), ${ }^{87}$ the penalties specified under the law of the parties for anti-pollution standards shall be 'adequate in severity to discourage violations' and 'shall be equally severe irrespective of where the violations occur'. ${ }^{88}$ Although MARPOL falls short of requiring that the penalties to implement the convention are of a criminal character, in practice many States have implemented the MARPOL enforcement provisions by means of criminal offences and penalties. ${ }^{89}$

Although the compatibility of the EU environmental crime directive with multilateral environmental agreements has not yet been tested by the Court of Justice of the EU, in Case C308/06 (Intertanko and others) (hereinafter 'Intertanko') ${ }^{90}$ the European Court of Justice (ECJ) had an opportunity to rule on the question of the compatibility of the 2005 Directive on ship-source pollution $^{91}$ with international law. Although this directive itself did not prescribe criminal sanctions for shipping pollution offences, it defined shipping pollution 'infringements' which were linked to a complementary EU Framework Decision which itself required the criminalisation of ship-source pollution. ${ }^{92}$ In its ruling handed down on 3 June 2008 , the ECJ held, similar to its decision in Peralta, ${ }^{93}$

${ }^{84}$ I99I Bamako Conventionion the Ban of the Import into Africa and the Control of the Transboundary Movement and Management of Hazardous wastes within Africa, (adopted 30 January 1991, entered into force 22 April 1998), reprinted in African Yearbook of International Law 269.. Article 9 reads "Each Party shall introduce appropriate national legislation for imposing criminal penalties on all persons who have planned, carried out, or assisted in such illegal imports. Such penalties shall be sufficiently high to both punish and deter such conduct." (emphasis added).

85 See further, Pereira, supra n. 23.

86 Seeart 8, par. I of the Convention on the International Trade of Endangered Species, 27 UST ro87 (adopted 3 March I973, I July 1975)

87 Convention on Prevention of Marine Pollution from Ships 1973/1978, I340 UNTS I84 (MARPOL) (adopted 2 November 1973, entry into force 2 October 1983).

88 Article 4 (4) ibid.

89 See I. Bantekas, International Criminal Law (Hart Publishing, Oxford, 2010). This includes the EU Member States with the adoption of the directive on ship-source pollution, as amended in 2009 to require the EU Member States to introduce criminal offence and penalties. See Directive 2005/35/EC of the European Parliament and of the Council on ShipSource Pollution and on the Introduction of Penalties for Infringements, 7 September 2005, OfficialJournal L 255/Ir; 30.9.2005 and Directive 2009/I23/EC of theEuropeanParliament and of the Council of 2I October 2009 amendingDirective 2005/35/EC onship-sourcepollution and ontheintroduction of penaltiesforinfringements; OfficialJournal, L $280 / 52$. 27.10.2009. In the UK context, seeSection I3I of the UK's Merchant Shipping Act 1995 Reg. I2. I3 amd 36 of the Prevention of Oil Pollution Regulations U.S. Act to Prevent Pollution from Ships (APPS) 33 USC. See also, Pereira, supra n23.

90 Case C-308/06 The Queen on the Application of: International Association of Independent Tanker Owners (Intertanko), International Association of Dry Cargo Shipowners (Intercargo), Greek Shipping Co-operation Committee, Lloyd's Register, International Salvage Union $v$ Secretary of State for Transport, 3 June 2008.

${ }^{2}$ Directive 2005/35/EC of the European Parliament and of the Council on Ship-Source Pollution and on the Introduction of Penalties for Infringements, 2003/0037 (COD).

92 Council Framework Decision 2005/667/JHA to Strengthen the Criminal-Law Framework for the Enforcement of the Law against Ship-Source Pollution. This decision-making mechanism was known (prior to the ratification of the Lisbon Treaty) as the 'double-text mechanism.' 
that the Community itself was not bound directly by the IMO International Convention for Prevention of Pollution from Ships ('MARPOL'), ${ }^{44}$ as the Community is not a signatory party to that Convention, despite the fact that all Member States are parties to it.95 Consequently, the ECJ could not review the legality of the shipping directive in light of MARPOL. ${ }^{6}$ As regards the legality of the Directive in light of the 1982 UN Convention on the Law of the Sea ('UNCLOS') ${ }^{97}$ - to which the Community is a party - the ECJ held that the Community was bound by that Convention and that it formed an integral part of the Community legal order..$^{98}$ Yet the court held that the nature and broad logic of UNCLOS precluded the examination of the validity of the shipping directive in light of its provisions, as UNCLOS was not directly applicable in the EU legal order ${ }^{99}$ as it does not aim to create rights for individuals or companies, such as shipping companies. ${ }^{100}$ On this basis, the ECJ ultimately declared that it was not possible for the court to examine the compatibility of directive on shipping pollution with either MARPOL or UNCLOS.

The court was correct to hold that a provision of an international agreement must be unconditional and sufficiently precise (and must confer rights on individuals), before it can be regarded to be directly effective in the Community/Union legal order. Yet the court failed to consider the exceptions to that rule recognized in previous case-law, namely in cases in which the Community/Union act aims at giving effect to an international agreement ${ }^{\text {ror }}$ or where the Community/Union act expressly refers to the international agreement. ${ }^{\mathrm{IO2}}$ In particular, unlike is the case with MARPOL (to which the EC is not a party), the Union/Community is bound UNCLOS, so it is regrettable that the Court in Intertanko does not assess the references to that Convention in the shipping pollution directive $\mathrm{e}^{\mathrm{ro3}}$ in order to establish whether it was necessary to apply the test of direct effect of international agreements or not. In other words, the Court could have assessed the legality of the shipping pollution directive in light of UNCLOS given the references in the former to the latter, regardless of whether or not UNCLOS has direct effect and confers rights on individuals. However, it is important to note that there are no references to UNCLOS in the provisions of the shipping pollution directive which were contested in this legal action (namely Articles 4 and 5 (2));

93 Case C-379/92 Peralta [1994] ECR I-3453, para. I6.

94، MARPOL' supra (n88)

95 For further on this case, see R. Pereira, 'On the Legality of the Ship-Source Pollution 2005/35/EC Directive: the Intertanko Case and Selected Others', I7 European Energy of Environmental Law Review(2008)pp. 372-383.

96 Intertanko, para. 50: "Since the Community is not bound by Marpol 73/78, the mere fact that Directive 2005/35 has the objective of incorporating certain rules set out in that Convention into Community law is likewise not sufficient for it to be incumbent upon the Court to review the directive's legality in the light of the Convention."

97 UN Convention on the Law of the Sea, 1833 UNTS 3 (adopted Io December 1982, in force 16 November 1994) ('UNCLOS')

${ }_{98}$ Intertanko, para. 53

99 Ibid.

Ioo Ibid. See NV International Fruit Company and others v Commission of the European Communities, Joined cases $4 \mathrm{I}$ to 44-70, I3 May 1971. See also, Pereira, supra n. 96.

ror See Case C-69/89 Nakajima v Council [1991] ECR I-2069.

Io2 Case 70/87 Fediol $v$ Commission [1989] ECR 1781. See also Case C-280/93 Germany v Council [1994] ECR I-4973).

${ }^{103}$ See Article 3 (I) (c), Article 7 (2) and Article 9 of the ship-source pollution directive. 
and the main objective of the shipping pollution directive appears to be to implement MARPOL, rather than UNCLOS, standards. ${ }^{104}$

The decision of the ECJ in Intertanko suggests that the court will be cautious to review the legality of EU secondary (environmental crime) legislation in light of multilateral environmental agreements, even in the case of international agreements to which the EC/EU are parties. The court's restrictive approach suggests that only exceptionally will the court recognise direct effect to international agreements. This appears to bean attempt by the court to maintain the delicate balance between the the international and EU legal orders; and to preserve the EU's position in negotiating and adopting such international agreements. Yet the disadvantage of court's restrictive approach is that it considerably limits the access of individuals to an effective remedy before the national courts to challenge the legality of EU secondary legislation in light of international environmental agreements.

\section{CONCLUSIONS}

Although there are significant differences between the provisions of the Council of Europe convention and the EU environmental crime directive, it does not appear that the former 'affects common rules' or 'alter their scope' to a significant extent so as to make the two instruments incompatible. Indeed, both instruments share the common goal of providing a legal framework for interstate criminal-law cooperation to combat environmental crime and for harmonisation of national environmental law in Europe. So it is unlikely that the minimum standards adopted in each instrument could be regarded as incompatible. Whereas at times the Council of Europe adopts certain higher standards than the EU environmental crime directive (eg as regards the definition of criminal penalties), at other times the environmental crime directive imposes higher standards (eg by requiring the criminalisation of wildlife crime and trade in ozone-depleting substances). But the existence of these differences does not mean that those instruments are incompatible. If a EU Member State (eg Estonia) were to be bound by both the Council of Europe convention and the EU environmental crime directive, it would have to adopt as a minimum the highest standard recognized in either instrument. The survey carriedout in this paper of specific provisions of the directive and Council of Europe conventionon environmental crime does notsuggest that there are fundamental differences between the two instruments which could render them incompatible and thus affect or alter the scope of the common EU rules.

Therefore, it is suggested that the EU member states remain competent to negotiate and ratify independently the Council of Europe convention, despite the exercise of the EU's internal legislative powers through the adoption of the environmental crime directive. This conforms with the principle recognized by the Court of Justice of the EU that, in general, the adoption of EU directives imposing minimum standards only gives rise to non-exclusive EU external competences to negotiate and adopt international agreements. It is also notable that although the Council of Europe environmental crime

\footnotetext{
${ }^{104}$ See also Pereira, supra n. 96.
} 
convention lacks a 'disconnection clause' to preserve the EC/Union interests, this generally doesnot pose a challenge to the recognition of external powers of the EU member states.

This potential co-existence between the Council of Europe convention and the EU environmental crime directive means that those two instruments could be regarded as complementary, as is the case with other Council of Europe and EU multilateral criminal-law cooperation agreements. ${ }^{\text {Ios }}$ Indeed, the Council of Europe convention could potentially provide the framework for broader environmental criminal-law cooperation across the European continent (and potentially even globally), while the EU environmental crime directive provides the basis of cooperation among the EU member states. Yet in theevent of an incompatibility between the EU environmental crime directive with multilateral environmental agreements in general, the Intertanko judgment suggests that the Court of Justice of the EU may not review the legality of the directive because of its restrictive view of the extent to which the provisions of multilateral agreements are directly effective in the EU legal order.

ros See the Council of Europe Criminal Law Convention on Corruption CETS No.: I73 and the EU Council Framework Decision 2003/568/JHA of 22 July 2003 on Combating Corruption in the Private Sector, OJ L328 (2003), at 54; OJC195/2 (1997); OJ L279/I (1997); OJ L358/2 (1998); the Council of Europe Convention on Cybercrime CETS no. I85 and the EU Council Framework Decision 2005/667/JHA of 24 February 2005 on Attacks Against Information Systems, OJ L69 (2005), at 67; and Council of Europe Convention on Action against Trafficking in Human Beings, Warsaw, 3 May 2005 (CETS No. 197) and Council Framework Decision 2002/629/JHA of I9 July 2002 on Combating Trafficking in Human Beings, OJ L2OO3 (2002), at 2). 